\title{
The Importance of Growth Factors and Steroid Hormones in Ovarian Cancer
}

\author{
Simon P. Langdon Dana Faratian David J. Harrison \\ Breakthrough Breast Unit and Division of Pathology, University of Edinburgh, United Kingdom
}

Activation of growth factor and hormonal signalling pathways can play critical roles in the development and progression of many cancers. Identifying which pathways are overexpressed within tumours may help implicate putative pathways that are driving growth and survival and indicate potential therapeutic targets.

In this issue of OnKologie, An and colleagues report a study describing associations between expression levels of insulin-like growth factors (IGFs) and their receptors with malignancy in ovarian cancer [1]. They show that higher levels of mRNA expression of both IGF-I and IGF-IR were present in malignant compared to benign disease and this was more evident in pre-menopausal than post-menopausal women. Both IGF-I and IGF-IR expression were increased in advanced (stage III/IV) cancer compared to early disease and in poorly differentiated tumours compared to well differentiated tumours. Oestrogen receptor $\alpha(\mathrm{ER} \alpha)$ expression levels were also significantly higher in malignant than benign tumours. This report provides further evidence that both the IGF and oestrogen pathways might be implicated in this disease and appears to be the first to demonstrate this in a Chinese rather than a Caucasian population.

The concept that both IGFs and oestrogen could be drivers of ovarian cancer is very much in line with previous studies $[2,3]$. Increased IGF-I levels have not only been described within ovarian cancers [2], but also in serum from women who have ovarian cancer [4]. Other components of the IGF system including IGF-II expression have been associated with outcome of ovarian cancer and linked to an increased risk [5]. IGF binding proteins (IGFBPs), which help regulate the interaction of the growth factor with the receptor, associate with outcome; increased expression levels of both IGFBP1 and IGFBP2 are directly associated with increased risk of ovarian cancer [6, 7] while IGFBP3 is protective [7]. Together these data support the idea that aberrations in and overexpression of the IGF signalling network contribute to the development of many ovarian cancers.

An and colleagues report that high expression of both IGF-I and IGF-IR were associated with advanced stage and high-grade tumours, while higher IGF-IR levels were associated with suboptimal debulking or residual tumour [1]. It has recently been shown that the IGF signalling network may be important not just as a driver of ovarian cancer growth and progression but is also implicated in resistance to platinum treatment, the cornerstone of cytotoxic therapy for this disease. Increased IGF-IR expression and IGF-I autocrine drive can lead to hyperactivation of the IGF pathway and this process has been linked to the development of platinum resistance within ovarian cancer cells [8]. Targeting the IGF-IR or its downstream effector pathways (such as MAPK or PI3K) may therefore lead to reversal of such resistance, and inhibitors of IGF-IR are currently undergoing preclinical testing [9] and trial in early phase clinical studies.

Another finding reported by An et al. was that of higher expression of ER $\alpha$ in ovarian cancers [1]. Use of preclinical models has demonstrated that oestrogen can regulate both gene expression and proliferation in ovarian cancer cells expressing high levels of $\mathrm{ER} \alpha$ [3]. The notion has developed that $\mathrm{ER} \alpha$ expression increases with disease progression while ER $\beta$ isoform expression decreases [10]. Ovarian cancers with high levels of ER $\alpha$ expression have been shown to be amenable to treatment with either tamoxifen or the aromatase inhibitor letrozole, further implying a functional role and demonstrating that this receptor can be usefully targeted [11].

Further studies are now required to more specifically define where increased growth factor and hormonal expression play a significant role in individual cancers. This study used RT-PCR to assay IGF-I, IGF-IR and ER on frozen tissue

\section{KARGER}

Fax +497614520714

Information@Karger.de

www.karger.com (c) 2009 S. Karger GmbH, Freiburg

Accessible online at:

www.karger.com/onk
Dr. Simon P. Langdon

Breakthrough Breast Unit and Division of Pathology

University of Edinburgh

Crewe Road South, Edinburgh EH4 2XU, United Kingdom

Tel.+44 131 537-1763, Fax -3159

simon.langdon@ed.ac.uk 
obtained at operation. These results require validation using immunohistochemistry on standard formalin-fixed, paraffinembedded material obtained during pathological examination so that these results may be translated into a usable clinical test. Downstream pathway responses that emanate from either IGF or oestrogen signalling are under development as potential biomarkers to help define where these pathways are active and influencing cell fate [12,13], and measurements of phospho-proteins (which are one measure of the functional state of a protein) may be of use in assaying responses to in- hibitors which target pathways such as IGF-I and its effectors [9]. An improved understanding of the significant drivers of ovarian cancer should eventually lead to more effective use of targeted therapies and help define more personalised approaches to cancer treatment.

\section{Conflict of Interest}

The authors have no conflicts of interest to declare.

\section{References}

1 An Y, Cai L, Wang Y, Zhu D, Guan Y, Zheng J: Local expression of insulin-like growth factor-1, insulin-like growth factor-1 receptor and estrogen receptor-a in ovarian cancer. Onkologie 2009;32: 638-644.

2 Brokaw J, Katsaros D, Wiley A, Lu L, Su D, Sochirca O, de la Longrais IA, Mayne S, Risch H, $\mathrm{Yu} \mathrm{H}$ : IGF-I in epithelial ovarian cancer and its role in disease progression. Growth Factors 2007 25:346-354.

3 Langdon SP, Smyth JF: Hormone therapy for ovarian cancer. Curr Opin Oncol 2008;20:548-553.

4 Lukanova A, Lundin E, Toniolo P, Micheli A, Akhmedkhanov A, Rinaldi S, Muti P, Lenner P, Biessy C, Krogh V, Zeleniuch-Jacquotte A, Berrino F, Hallmans G, Riboli E, Kaaks R: Circulating levels of insulin-like growth factor-I and risk of ovarian cancer. Int J Cancer 2002;101:549-554.

$\checkmark 5$ Lu L, Katsaros D, Wiley A, Rigault de la Longrais IA, Risch HA, Puopolo M, Yu H: The relationship of insulin-like growth factor-II, insulin-like growth factor binding protein-3, and estrogen receptoralpha expression to disease progression in epithelial ovarian cancer. Clin Cancer Res 2006;12:12081214
6 Lancaster JM, Sayer RA, Blanchette C, Calingaert B, Konidari I, Gray J, Schildkraut J, Schomberg DW, Marks JR, Berchuck A: High expression of insulin-like growth factor binding protein-2 messenger RNA in epithelial ovarian cancers produces elevated preoperative serum levels. Int J Gynecol Cancer 2006;16:1529-1535.

7 Dal Maso L, Augustin LS, Franceschi S, Talamini R, Polesel J, Kendall CW, Jenkins DJ, Vidgen E, La Vecchia C: Association between components of the insulin-like growth factor system and epithelial ovarian cancer risk. Oncology 2004;67:225-230.

8 Eckstein N, Servan K, Hildebrandt B, Pölitz A, von Jonquières G, Wolf-Kümmeth $\mathrm{S}$, Napierski I, Hamacher A, Kassack MU, Budczies J, Beier M, Dietel M, Royer-Pokora B, Denkert C, Royer HD: Hyperactivation of the insulin-like growth factor receptor I signaling pathway is an essential event for cisplatin resistance of ovarian cancer cells. Cancer Res 2009;69:2996-3003.
9 Sabbatini P, Rowand JL, Groy A, Korenchuk S, Liu Q, Atkins C, Dumble M, Yang J, Anderson K, Wilson BJ, Emmitte KA, Rabindran SK, Kumar R: Antitumor activity of GSK1904529A, a small-molecule inhibitor of the insulin-like growth factor-I receptor tyrosine kinase. Clin Cancer Res 2009;15:3058-3056.

10 Bardin A, Hoffmann P, Boulle N, Katsaros D, Vignon F, Pujol P, Lazennec G: Involvement of estrogen receptor $\beta$ in ovarian carcinogenesis. Cancer Research 2004;64:5861-5869.

11 Smyth JF, Gourley C, Walker G, et al.: Antiestrogen therapy is active in selected ovarian cancer cases: the use of letrozole in estrogen receptorpositive patients. Clin Cancer Res 2007;13:3617-3622.

12 Walker G, MacLeod K, Williams ARW et al.: Insulin like growth factor binding proteins IGFBP3, IGFBP4 and IGFBP5 predict endocrine responsiveness in patients with ovarian cancer. Clin Cancer Res 2007;13:1438-1444.

13 Walker G, MacLeod K, Williams ARW et al.: Estrogen-regulated gene expression predicts response to endocrine therapy in patients with ovarian cancer. Gynecol Oncol 2007; 106:461-468. 